\title{
Flow-cytometric mapping provides novel insights into the seasonal and vertical distributions of freshwater autotrophic picoplankton
}

\author{
Nicholas D. Crosbie ${ }^{1,2, *}$, Katrin Teubner $^{1}$, Thomas Weisse $^{1}$ \\ ${ }^{1}$ Institute for Limnology of the Austrian Academy of Sciences, Mondseestr. 9, Mondsee 5310, Austria \\ ${ }^{2}$ Present address: Ocean Genome Legacy, 32 Tozer Road, Beverly, Massachusetts 01915, USA
}

\begin{abstract}
This is the first study using flow cytometry to characterize the population dynamics of freshwater autotrophic picoplankton (APP) over a full seasonal cycle, the goal of which was to accurately quantify and qualify the natural APP populations in relation to major environmental parameters. In particular, we wanted to test current assumptions about the seasonal succession of prokaryotic and eukaryotic picoplankton cells, including the relationship between solitary picocyanobacteria and microcolonies. Using flow cytometry, we were able to efficiently characterize the abundances of 4 lake APP assemblages in Lake Mondsee, including that of a solitary picocyanobacterial population exhibiting high 'side scatter' values. Such cells were not readily enumerated by epifluorescence microscopy. Unlike Lakes Constance and Maggiore, we found no evidence of a spring peak in solitary picocyanobacteria - we propose that the lack of a spring peak in Lake Mondsee was due to weak stratification in March-April and relatively deep vertical mixing. Since summer declines in the abundance of solitary picocyanobacteria were associated with extended periods of reduced light availability, it is likely that such declines were in part due to low relative growth rates. Finally, we argue that the formation of microcolonies by picocyanobacteria is unlikely to be a strategy for more efficient nutrient recycling (e.g. Stockner \& Antia 1986). Rather, we suggest that microcolonies reach high concentrations in surface and near-surface waters due to the production of a photosynthate-rich mucilage resulting from active photosynthesis during periods of severe nutrient deficiency.
\end{abstract}

KEY WORDS: Microcolonies · Picocyanobacteria - Eukaryotic picoplankton · Flow cytometry · Sorting $\cdot$ Lakes $\cdot$ Calcite $\cdot$ Calcium carbonate

Resale or republication not permitted without written consent of the publisher

\section{INTRODUCTION}

Autotrophic picoplankton (APP) play a major role in the microbial food web of many lakes (reviewed by Stockner \& Antia 1986, Weisse 1993, Fogg 1995, Bell \& Kalff 2001). Limnologists have thus contributed to a body of knowledge which permits some generalization about the seasonal succession of APP in broad functional groups in oligo-mesotrophic temperate lakes. Spring peaks and, more often, early and/or late summer peaks of 'solitary' picocyanobacterial cells are common in many lakes (Fahnenstiel et al. 1986, Weisse 1988, Callieri \& Stockner 2000). In some instances (e.g. Lake Maggiore, Great Laurentian Lakes), those maxima are closely followed by peaks in the abundance of sus- pended picocyanobacterial colonies (henceforth, 'microcolonies'), which may also exhibit an autumn peak (Klut \& Stockner 1991, Fahnenstiel \& Carrick 1992, Passoni \& Callieri 2000). Microcolonies are defined herein as 4 or more 'loosely' to 'tightly' clustered cells which unlike 'aggregates', contain picocyanobacteria of similar or apparently identical morphology (e.g. 'rod', 'Coccoid' or 'ovoid'). Eukaryotic autotrophic picoplankton (EAP) are usually an order of magnitude less numerous in lakes than picocyanobacteria but, due to their larger size, may reach a similar biomass to that obtained by solitary picocyanobacteria (Pick \& Agbeti 1991). Peak abundances of EAP are normally observed during spring isothermal mixing/early thermal stratification (summarized by Callieri \& Stockner 2002). 
Whilst the overall seasonal pattern of APP abundance in oligo-mesotrophic temperate lakes appears to be reasonably well described, there remains considerable uncertainty as to the taxonomic identity of the various populations and the extent to which different environmental and ecological factors are responsible for the observed seasonal trends (Weisse 1993, Callieri \& Piscia 2002). Experimentation has been used in previous studies in attempts to identify potential causal factors (e.g. Weisse 1988, Wehr 1991). In lieu of direct manipulation, researchers have also used regression techniques and/or have undertaken time-series studies to identify which measured variables are likely to causally influence the seasonal abundance of autotrophic picoplankton (Gaedke \& Weisse 1998, Callieri \& Piscia 2002).

We present herein the results of flow-cytometric APP analyses conducted during 2 consecutive years in oligo-mesotrophic prealpine Lake Mondsee (Austria) in order to characterize vertical and temporal distributions of APP abundance. Although several marine studies have demonstrated the efficiency and sensitivity of flow cytometry (e.g. Li \& Wood 1988, Crosbie \& Furnas 2001a), the technique has rarely been applied by limnologists in field studies of APP (but see Fahnenstiel et al. 1991). The goal of this study was to accurately quantify and qualify the natural APP populations in relation to the major environmental parameters. In particular, we wanted to test current assumptions about the seasonal succession of prokaryotic and eukaryotic picoplankton cells (Weisse 1993, Callieri \& Stockner 2002), including the relationship between solitary picocyanobacteria and microcolonies (Callieri \& Stockner 2000, 2002, Stockner et al. 2000). After careful calibration of flow-cytometric data by epifluorescence microscopy and flow-cytometric cell sorting, we were able to efficiently characterize seasonal and vertical variability in the abundances of 4 lake APP assemblages, including that of a solitary picocyanobacterial population exhibiting high 'side scatter' values when analyzed by flow cytometry. Such cells, as well as eukaryotic picoplankton, were not readily enumerated by epifluorescence microscopy.

\section{MATERIALS AND METHODS}

Sampling and measurement of environmental parameters. Seasonal variability in APP abundance was characterized for a 2 yr period (from January 2000 to December 2001) by fortnightly sampling conducted between 09:00 and 10:00 h (local time) at the deepest location of oligo-mesotrophic, prealpine Lake Mondsee $\left(47^{\circ} 48^{\prime} \mathrm{N}, 13^{\circ} 22^{\prime} \mathrm{E}\right.$; area $=14.2 \mathrm{~km}^{2}$; maximum depth $=68 \mathrm{~m})$. Details on the morphometry, hydrology and eutrophication history of Lake Mondsee are given in Jagsch (1982), Dokulil \& Jäger (1985), Dokulil \& Skolaut (1986) and Klee \& Schmidt (1987).

Duplicate subsamples for the analysis of dissolved inorganic nutrients $\left(\mathrm{NO}_{3}-\mathrm{N}, \mathrm{PO}_{4}-\mathrm{P}\right)$ and total phosphorus (TP), chl a and APP populations were obtained from a Schindler bottle triggered at discrete depths, and from a Schröder bottle used to obtain an integrated sample of the surface $20 \mathrm{~m}$ water column. Nutrient and chl a concentrations were determined from fresh samples by standard techniques (APHA 1992). Samples for APP counts were fixed with paraformaldehyde $\left(0.2 \%\right.$ final conc.), kept in the dark at $4{ }^{\circ} \mathrm{C}$ for $<48 \mathrm{~h}$ prior to being analyzed by flow cytometry, or gently filtered onto $25 \mathrm{~mm}$ diameter $0.2 \mu \mathrm{m}$ Isopore $^{\mathrm{TM}}$ membranes (Millipore, filter code GTBP) and kept in the dark at $4^{\circ} \mathrm{C}$ for $<2$ wk prior to being analyzed by epifluorescence microscopy.

Temperature and $\mathrm{pH}$ were recorded by a profiling instrument (Yellow Springs Instruments). Density was calculated according to Bäuerle et al. (1998). The depth of the upper hypolimnetic boundary was determined from density profiles by graphical means (i.e. point of inflection, see Cole 1994). Irradiance profiles were measured using an underwater spherical Li-Cor photosynthetically active radiation (PAR) sensor. Vertical attenuation coefficients for scalar irradiance were calculated according to the equation of Kirk (1994):

$$
\ln E_{\mathrm{d}}(z)=-K_{\mathrm{d}} z+\ln E_{\mathrm{d}}(0)
$$

where $E_{\mathrm{d}}(z)$ and $E_{\mathrm{d}}(0)$ are the values of downward irradiance at $z \mathrm{~m}$ and just below the surface, respectively. The linear regression coefficient of $\ln E_{\mathrm{d}}(z)$ with respect to depth gives the attenuation coefficient, $K_{\mathrm{d}}$.

Sunlight hours (Lake Wolfgang, Year 2000) or surface PAR (Lake Mondsee, Year 2001) were measured by weather stations located on Lake Mondsee or at nearby Lake Wolfgang. Sunlight hours for Year 2000 were subsequently converted to daily mean instantaneous surface PAR ( $\left.\mathrm{SPAR}_{\text {Inst.-mean }}\right)$ values according to the relationship:

$$
\mathrm{SPAR}_{\text {Inst.-mean }}=44.99(\text { Day of Year })+108.59
$$

where $\mathrm{SPAR}_{\text {Inst.-mean }}$ was calculated as the daily mean of the integration of hourly averages derived from minutebinned surface PAR data. Calculation of SPAR Inst.-mean from Eq. (2) was restricted to a $130 \mathrm{~d}$ period between Days 110 and 240 (Day 1 = January 1), during which Lake Wolfgang sunlight hours and Lake Mondsee SPAR Inst.-mean are well correlated $\left(\mathrm{r}^{2}=0.90\right.$ for Year 2001). To obtain estimates of daily light dose, daily mean instantaneous underwater light values were calculated from SPAR and $K_{\mathrm{d}}$ (neglecting fluctuations in $K_{\mathrm{d}}$ within a given day) and expressed as a depthweighted average for the surface $12 \mathrm{~m}$ water column (DWA-UPAR Inst.-mean). 
Flow-cytometric counts of APP populations. A 3-color FACSCalibur ${ }^{\mathrm{TM}}$ (BD Systems) equipped with an argon laser (power $=15 \mathrm{~mW}$, at $488 \mathrm{~nm}$ ), autoloader and FACSFlow Supply System ${ }^{\mathrm{TM}}$ (BD Systems) was used to enumerate APP populations. The photomultipliers were set to quantify: red fluorescence (wavelength > $650 \mathrm{~nm})$, orange fluorescence $(564-606 \mathrm{~nm})$, and green fluorescence (515-545 nm). For each cell, 2 lightscatter parameters (side scatter and forward light scatter) and 4 fluorescence parameters (peak heights of green, orange and red fluorescence, plus peak area of orange fluorescence) were recorded on 4-decade logarithmic scales, with the exception of peak area of orange fluorescence which was recorded on a linear scale (Fig. 1). Fixed $3 \mathrm{ml}$ subsamples were pipetted into FALCON ${ }^{\mathrm{TM}}$ tubes (BD Systems), each containing $100 \mu \mathrm{l}$ of working concentration (ca. 3000 beads $\mathrm{ml}^{-1}$ ) calibration-grade $0.92 \mu \mathrm{m}$ yellow-green fluorescent beads (Polysciences), gently vortexed and loaded onto a FACS Loader ${ }^{\mathrm{TM}}$ carousel (BD Systems).

Using WorklistManager ${ }^{\mathrm{TM}}$ software (v. 3.1f, BD Systems), data acquisition was automatically delayed for a period of $15 \mathrm{~s}$ prior to the analysis of individual samples to allow the autoloader to gently shake the samples $(5 \mathrm{~s})$, to flush the sample interrogation cuvette with new sample and to allow the flow rate to stabilize
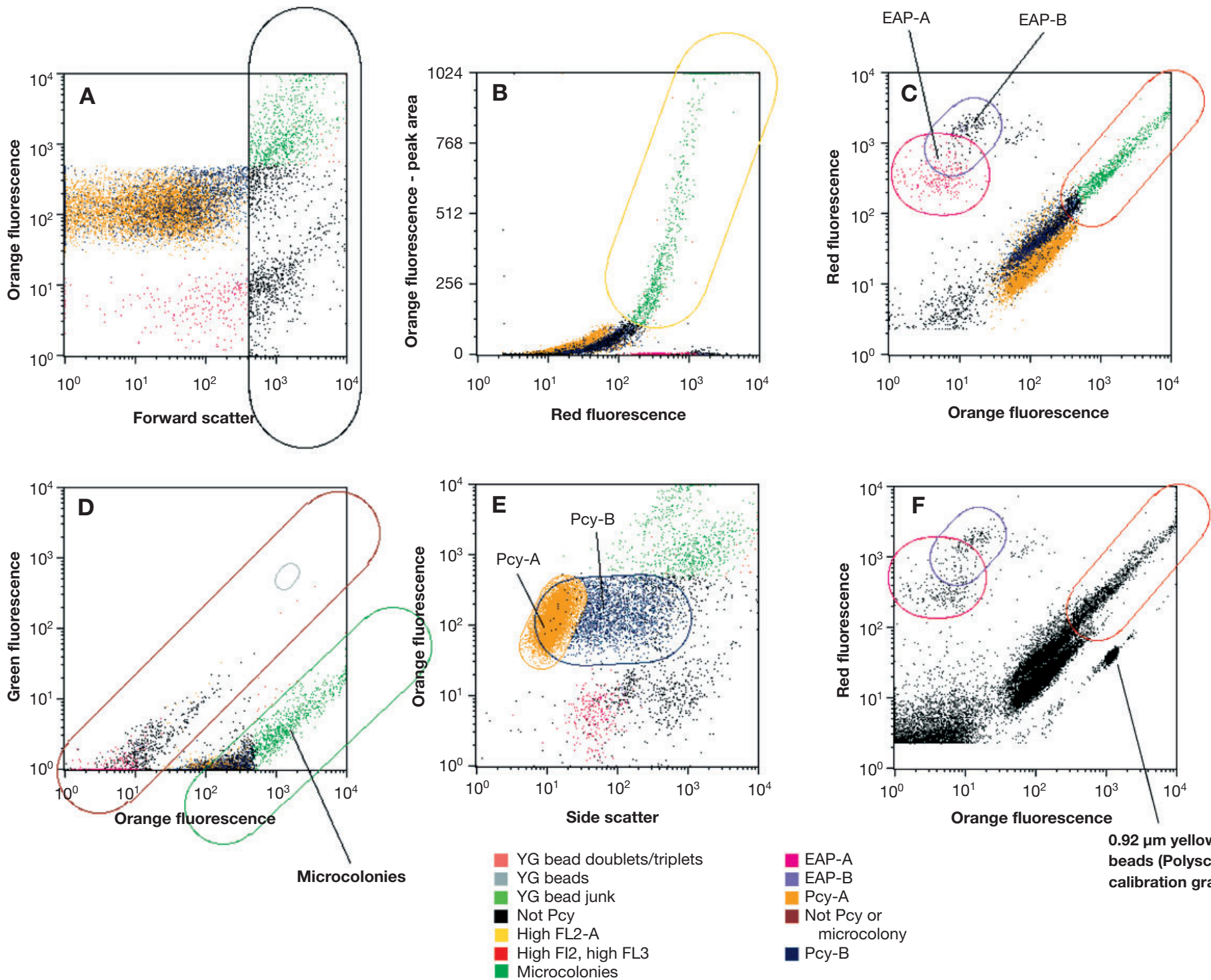

$0.92 \mu \mathrm{m}$ yellow-green beads (Polysciences, calibration grade)

Fig. 1. Classification of autotrophic picoplankton (APP) populations using Attractors ${ }^{\mathrm{TM}}$ software. Attractor methods work on the principle of defining 1 attractor for each population of interest. An attractor is a user-defined population boundary that processes and counts the number of events in a population. The process of analysis is hierarchical, that is, subattractors only process the part of the data distribution that its ancestor attractors have been able to classify (i.e. YG bead doublets/triplets population classified first, Pcy-B population classified last). Panel (F) shows unprocessed data. YG = yellow green. Pcy = 'solitary' phycoerythrin-rich picocyanobacteria exhibiting low (Pcy-A) or high (Pcy-B) side scatter. EAP = eukaryotic picoplankton, classified as either 'EAP-A' or 'EAP-B' (EAP-A cells were most clearly-separated from EAP-B cells at the end of spring isothermal mixing/commencement of water column stratification, at which time EAP-B cells remained relatively rare) 
(10 s). Samples were run for $3 \mathrm{~min}$ at high flow rate so that ca. $200 \mu \mathrm{l}$ was analyzed per sample. Flow rate was determined by an adaptation of the gravimetric protocol of Olson et al. (1993). Specifically, the flow rate was given by the regression slope of analyte weight-change versus time, plotting the results from 6 FALCON ${ }^{\mathrm{TM}}$ tubes filled with standard analyte $(3 \mathrm{ml}$ of integrated sample added to $100 \mu \mathrm{l}$ of bead working stock; FACSFlow ${ }^{\mathrm{TM}}$ sheath fluid, BD Systems), analyzed for periods of between 0.5 and 12 min using standard instrument settings. Flow rate was determined weekly or more often if fluctuations in sample voltage were observed. Sheath fluid quality and potential bias due to tube position were assessed from duplicate control tubes added to every sample set. We found no significant difference between APP counts of the same sample added to tubes at start and end positions of a given sample set (paired $t$-tests).

Semi-automatic classification of APP populations was performed on CellQuest ${ }^{\mathrm{TM}}$ (v. 3.1f) data files using Attractors ${ }^{\mathrm{TM}}$ (v. 3.0.0) software (BD Systems) (Fig. 1). For flow-cytometric estimates of APP abundance, we used values calculated from flow rates since these were more precise (based on the \% difference between duplicate samples) than values calculated from bead concentrations. Total sample event rates were always 5- to 10 -fold below event rates at which co-incidence may become significant (ca. 500 events $\mathrm{s}^{-1}$ ).

Validation of flow-cytometric counts. For validation of flow-cytometric counts, subsamples of fortnightly discrete-depth and integrated samples from Spring, Summer and Autumn of 2001 were processed by flowsorting and epifluorescence microscopy in parallel to subsamples used for flow-cytometric counts. Direct epifluorescence counts of APP cells and microcolonies contained in 10 to $20 \mathrm{ml}$ of fixed sample were made using a Zeiss Axioplan microscope until at least 200 cells or microcolonies per APP category, i.e. 'solitary' eukaryotic picoplankton, 'solitary' forms of phycoerythrin-rich picocyanobacteria, 'solitary' forms of phycocyanin-rich picocyanobacteria, phycoerythrinrich microcolonies, or 40 random microscope fields, were enumerated. Morphometric measurements of solitary and colonial picocyanobacteria, and EAP cells, were made from images (Lucia Lab Systems) captured at a magnification of $1250 \times$ (Hitachi charge-coupled device [CCD], model KP-M1E/K).

Picocyanobacteria were differentiated from eukaryotic picoplankton based upon their epifluorescent characteristics under green and blue excitation (Weisse \& Kenter 1991, MacIsaac \& Stockner 1993). Phycoerythrin-rich cyanobacteria were characterized by their orange-red fluorescence under green and their yelloworange fluorescence under blue excitation. Phyco- cyanin-rich cyanobacteria and picoeukaryotes appeared purple-red or red at both green and blue excitation. They were differentiated from each other based on the presence or absence of a chloroplast. Microcolonies consisted of clusters of $\geq 4$ picocyanobacterial cells of similar size and shape. Colony-forming EAP and colony-forming phycocyanin-rich picocyanobacteria were rarely observed and not included in APP epifluorescence counts.

For cell sorting, between 1000 and 100000 APP cells or microcolonies from euphotic zone Lake Mondsee samples were sorted into microwells containing $2 \mathrm{ml}$ of Milli-Q by a FACS Vantage SETM flow cytometer equipped with ClonCyte ${ }^{\mathrm{TM}}$ software (v. 3.1, BD Systems) (Crosbie et al. unpubl.). After sorting, cells or microcolonies in half of the contents of each microwell were fixed with paraformaldehyde $(0.2 \%$ final conc.), then filtered and observed by epifluorescence microscopy. The remaining $1 \mathrm{ml}$ of sorted preparation was diluted to $3 \mathrm{ml}$ with Milli-Q, fixed with paraformaldehyde $(0.2 \%$ final conc.) and then analyzed on the FACSCalibur as previously described.

Microcolony fragmentation during flow-cytometric analysis. To gauge the extent to which microcolonies were fragmented during FACSCalibur analysis of APP populations, microcolonies in euphotic zone Lake Mondsee samples were sorted (FACS Vantage SE) into microwells containing $2 \mathrm{ml}$ of Milli-Q. A total of 8 microwells were filled with sorted microcolonies so that each microwell contained between ca. 200 and 1000 microcolonies. After fixation (paraformaldehyde, $0.2 \%$ final conc.), the microwell contents were transferred to FALCON tubes and half the tubes subjected to 5 min sonication (tubes submerged in a Bandelin Sonorex sonicator). Each $2 \mathrm{ml}$ volume of sonicated or unsonicated sorted microcolonies was further divided into 2 aliquots, 1 of which was gently filtered and observed by epifluorescence microscopy, the other diluted to $3 \mathrm{ml}$ with Milli-Q and analyzed on the FACSCalibur. The FACSCalibur instrument settings were those used for fortnightly flow-cytometric counts of APP populations, as described above.

Biomass estimates and \% contribution of APP. For Year 2001, the biomass of the total phytoplankton and the APP fraction was estimated from chl a concentrations measured in whole or size-fractionated $(50 \mathrm{~mm}$ diameter Nucleopore $^{\mathrm{TM}} 2.0 \mu \mathrm{m}$ membranes) 21 water samples filtered onto $47 \mathrm{~mm}$ diameter GF/F filters, assuming a carbon:chl a ratio of 22.5 (Søndergaard 1991).

Statistical analyses. The degree to which seasonal APP distributions correlated with temperature, nitrate, TP and $\mathrm{pH}$, was examined by hierarchical partitioning analysis (Chevan \& Sutherland 1991) of depthweighted average data using HIERARCH (v. 1.0; Chevan 1991). To improve normality (assessed by 
the Kolmogorov-Smirnov test, as implemented by SigmaStat $^{\circledR}$ V. 2.0 for Windows ${ }^{\circledR}$; SPSS 1997), APP abundances were $\log _{10}$-transformed. Whereas the usual goal of multiple regression is to produce the most predictive linear equation, hierarchical partitioning calculates the contribution of each independent variable to multivariate correlation within all possible linear model equations involving a given set of variables (i.e. what is the average effect of including Variable A in all first-order, i.e. just $\mathrm{B}, \mathrm{C}_{1} \ldots$, second-order, i.e. $\mathrm{BC}$, $\mathrm{BD}, \mathrm{BE}_{1}, \ldots$, and higher-order, i.e. $\mathrm{BCD}, \mathrm{BCE}, \ldots, \mathrm{BCDE}, \ldots$, models?) (Chevan \& Sutherland 1991). As such, hierarchical partitioning is likely to be more effective in addressing statistical artefacts introduced through multicollinearity (for a detailed discussion on the usage and interpretation of hierarchical partitioning and multiple regression techniques, see MacNally 2000).

Kriging. Seasonal and vertical distributions of APP, chl $a$ and selected environmental parameters were visualized in Surfer $^{\circledR}$ (v. 7, Golden Software 1999) by standard point kriging. Grid dimensions were set to 1000 rows $\times 1000$ columns.

\section{RESULTS}

Flow-cytometric characterisation of freshwater APP populations

Three picocyanobacteria populations (Pcy-A, Pcy-B and microcolonies) and 2 picoeukaryote populations (EAP-A and -B) could be differentiated by flow cytometry (Fig. 1). Pcy-A consisted entirely of phycoerythrin-rich, solitary coccoid and, to a lesser extent, solitary ovoid forms. They were characterized by their high orange fluorescence, combined with a low SSC signal (Fig. 1E). So-called 'microcolonies' consisted predominantly of an assemblage of tightly packed, phycoerythrin-rich coccoid, ovoid or rodshaped picocyanobacteria (Fig. 2). These microcolonies were identified based upon their relatively high red and orange autofluorescence (Fig. 1B,C); additionally, their green fluorescence, FSC and SSC signals were larger than those of unicellular picocyanobacteria (Fig. 1A,D,E). Cells sorted from Pcy-A and -B populations were indistinguishable when

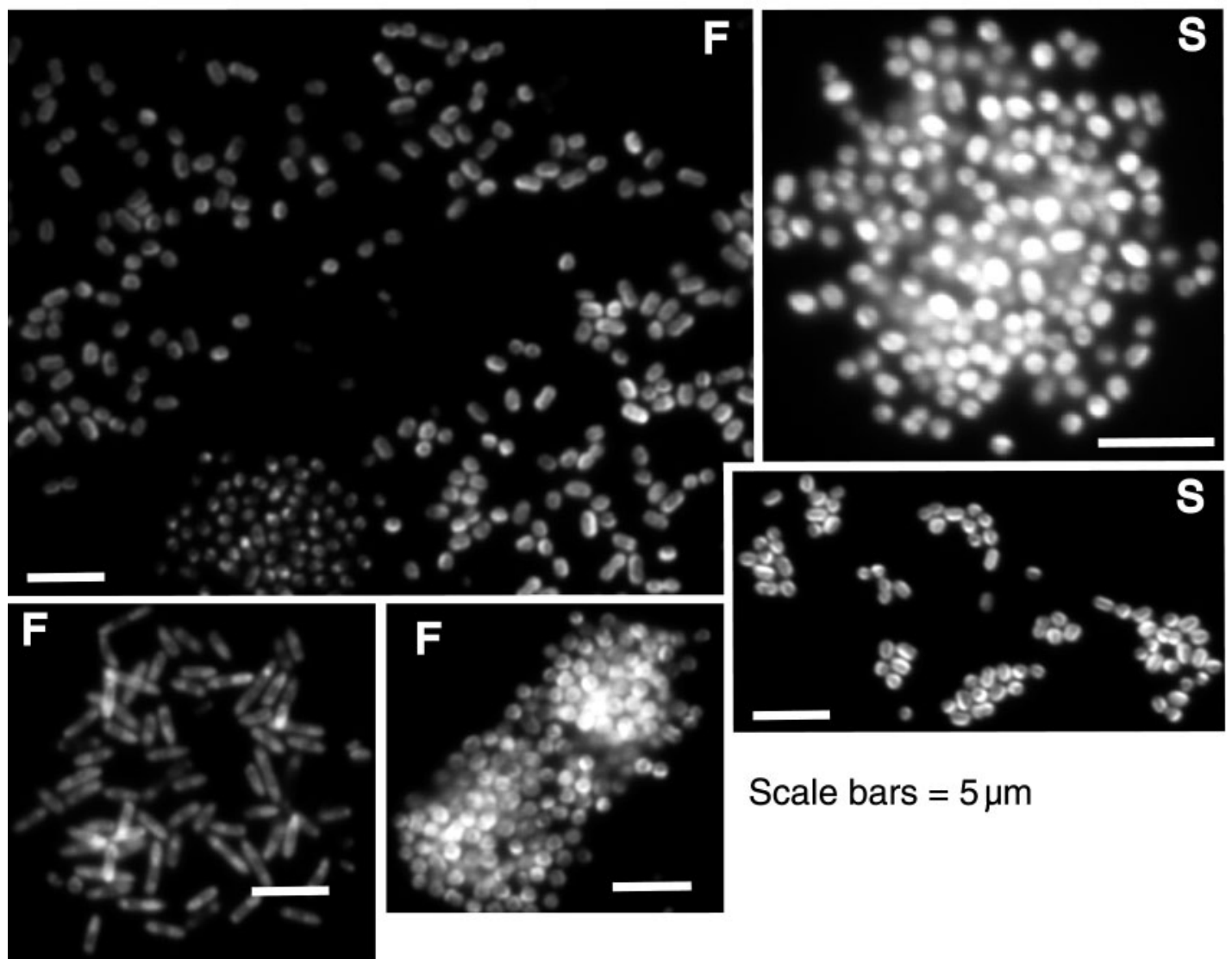

Fig. 2. Morphological diversity of microcolonies commonly observed in Lake Mondsee using green excitation. Pictures were taken using a CCD (Hitachi, model KP-M1E/K) coupled to a Zeiss Axioplan epifluorescence microscope. F = observed from filtered sample; $\mathrm{S}$ = observed from flow-cytometrically sorted sample 
viewed by epifluorescence microscopy, but readily distinguishable by flow cytometry based on sidescatter values (Fig. 1E). The cause of the high sidescatter values (Pcy-B cells) is presently not known, but might be due to calcite deposition on the surface (particularly the S-layer) of photosynthetically active cyanobacterial picoplankton (e.g. Thompson et al. 1997).

Phycocyanin-rich picocyanobacteria were either very rare $(<5 \%$ of APP abundance) or could not be observed amongst APP sorted from Lake Mondsee samples. Sorted EAP-A cells, with high-red and loworange fluorescence (Fig. 1C), were identified as solitary chlorophytes of spherical, ellipsoid, or slightly kidney-shaped morphology, similar to those described by Krienitz and co-workers (Krienitz et al. 1999, Hepperle \& Krienitz 2001). Sufficient material for microscopic identification of the relatively rare EAP-B cells also shown in Fig. 1 could not be obtained by cell sorting, and appeared not to be represented in our collection of laboratory isolates (authors' unpubl. data). Thus, we confine further discussion of Lake Mondsee picoeukaryotes to the population of EAP-A cells.
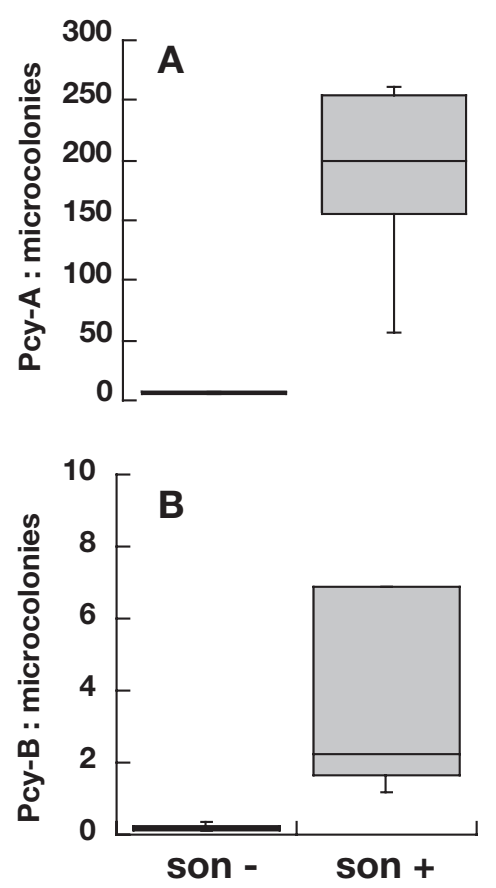

Fig. 3. Effect of sonification of sorted microcolonies on the ratio of (A) Pcy-A and (B) Pcy-B to microcolonies. son-: no sonification of sorted microcolonies; son+: sonification of sorted microcolonies in FALCON ${ }^{\mathrm{TM}}$ tubes for $5 \mathrm{~min}$ (see 'Materials and methods' section). Boxes show median, upper and lower quartiles. Min/max values (lines extending beyond each boxes) were calculated from: quartiles $\pm(1.5 \times$ interquartile distance)

\section{Microcolony fragmentation during flow-cytometric analysis}

Sonication of sorted microcolonies for 5 min resulted in ca. 30- and 40-fold enrichment of Pcy-A and -B cells, respectively, relative to unsonicated controls (Fig. 3). The latter yielded high purity 'microcolony signatures' when analysed by the FACSCalibur, i.e. sorted, but unsonicated material contained few Pcy-A or -B cells. Microcolony fragmentation during FACSCalibur analysis of Lake Mondsee APP populations would therefore appear to be minimal, a conclusion supported by morphometric measurements of microcolonies; the maximum length of most colonies was ca. 5- to 30-fold smaller than the smallest aperture (cuvette width $=$ $180 \mu \mathrm{m}$ ) of the FACSCalibur prior to analyses. Larger colonies, those most likely to be fragmented, were too rare to have significantly affected flow-cytometric counts of picocyanobacterial populations given the small volumes (ca. $200 \mu \mathrm{l}$ ) that were analysed (Crosbie et al. unpubl. data).

\section{Flow-cytometric and epifluorescence microscopy counts}

Epifluorescence microscopy counts of solitary picocyanobacteria, though well correlated $\left(\mathrm{r}^{2}=0.92\right)$, were significantly lower (a mean difference of ca. $20 \%$ for the abundance range, $4 \times 10^{3}$ to $268 \times 10^{3}$ cells ml $^{-1}$ ) than flow cytometric counts, pooling abundances of Pcy-A and -B populations (Fig. 4A). Although we did not pursue this finding systematically, we suspect that the lower epifluorescence microscopy counts resulted from a combination of factors, including operator fatigue, longer storage time and the associated inherent difficulty of counting dim and rapidly fading cells. In particular, the small size and dim red fluorescence of the EAP-A cells hampered attempts to quantify their abundance by epifluorescence microscopy, which underestimated their abundance when concentrations were low (data not shown).

Epifluorescence and flow-cytometric counts of microcolonies were also well correlated (Fig. 4B), but the rarity of large microcolonies resulted in them being poorly enumerated in the small volumes processed by flow cytometry; consequently, flow-cytometry underestimated microcolony abundance by an average of $39 \%$ (calculated for the abundance range, $0.5 \times 10^{3}$ to $7 \times 10^{3}$ cells ml${ }^{-1}$ ) (Fig. 4B).

The precision of flow cytometric counts was related to the abundance of APP cells. For example, at low, moderate and high abundances, the difference between duplicate counts of Pcy-A cells was $<10 \%$ (typically <5\%) when abundances exceeded ca. 5000 
cells $\mathrm{ml}^{-1}$. Up to ca. $100 \%$ difference between duplicate counts of samples was observed at very low APP abundances $\left(<500\right.$ cells $\left.\mathrm{ml}^{-1}\right)$.

\section{Biomass estimates and \% contribution of APP}

APP constituted between 8 (mid-December) and $45 \%$ (late September) of total photoautotrophic carbon (Fig. 5D). Relatively high contributions of noncolonial APP to total photoautotrophic carbon were restricted to the annual periods of water column stratification. Maximum contributions occurred during extended periods of high irradiance and low wind speeds. At such times, relatively low nutrient concentrations were observed throughout the euphotic zone, but particularly in near-surface waters (Fig. 5B,C). Conversely, the percent APP contribution to total phytoplankton carbon was relatively low during periods of vertical mixing caused by stormy weather
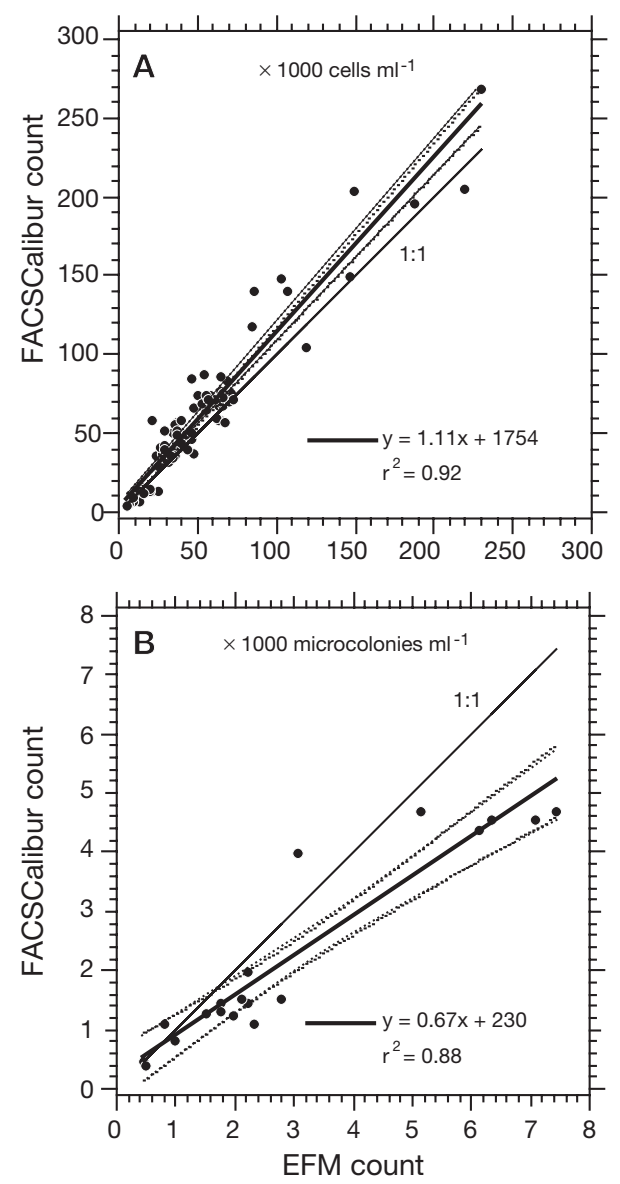

Fig. 4. Relationship between flow-cytometric and epifluorescence microscopy counts of (A) solitary picocyanobacteria and (B) microcolonies. Dotted lines show 95\% confidence limits for linear regression curve fits (thick solid lines) and/or low water temperatures (spring and autumn), but increased rapidly following restabilization of the water column (Fig. 5D).

\section{Seasonal and vertical distributions of APP}

An annual spring bloom of EAP-A cells occurred each year, commencing at or just prior to the end of spring isothermal mixing, and reaching a maximum as the water column began to stratify. Several minor peaks in the abundance of EAP-A cells, observed during summer and autumn months, were restricted mostly to the surface 4 to $6 \mathrm{~m}$ of the euphotic zone (Fig. 6A).

Standing stocks of Pcy-A and microcolony populations peaked during summer (Fig. 6B,D) when the epilimnion was strongly stratified, TP concentrations were low (Fig. 5C) and $\mathrm{PO}_{4}-\mathrm{P}$ concentrations (data not shown) were near or below detection limits. The subsurface maxima of picocyanobacterial APP extended from surface (microcolonies and Pcy-B populations, Fig. 6C,D) or near-surface (Pcy-A population, Fig. 6B) to depths where PAR was near $1 \%$ of surface light (Fig. 6B-D). In early Summer, the subsurface maxima of the Pcy-A population (Fig. 6B) extended deeper into the water column than did the subsurface maxima of microcolony and Pcy-B populations (Fig. 6C,D), but exhibited more reduced standing stocks at depths less than ca. $3 \mathrm{~m}$ (Fig. 6B). A close correspondence between vertical patterns of microcolony abundance and increasing water density (Fig. 7) suggests that a gradual (net) subsidence and/or downward mixing supplied lower epilimnion depths with microcolonies during June/July 2000.

Surface and near-surface abundances of microcolonies and solitary picocyanobacteria, particularly Pcy-B cells, were positively associated, with the exception of a single sampling date in August 2000 (after an extended period of poor weather), and following the intrusion of hypolimnetic waters in September 2001 (Fig. 6B-D), at which time, aggregation and rapid 'fallout' of microcolonies may have occurred; many large microcolonies were observed by epifluorescence microscopy in samples collected from the hypolimnion. A short-lived 'bloom' of solitary picocyanobacterial cells was observed following re-establishment of water column stratification (Fig. 6B,C).

Abundances of all APP populations, but not chl $a$, were positively correlated with water temperature and light availability when the respective parameters were integrated over the euphotic zone and the analysis was restricted to sampling dates when the water column was stratified (Fig. 8). Pcy-A cells and microcolonies exhibited declines in standing stocks when light avail- 


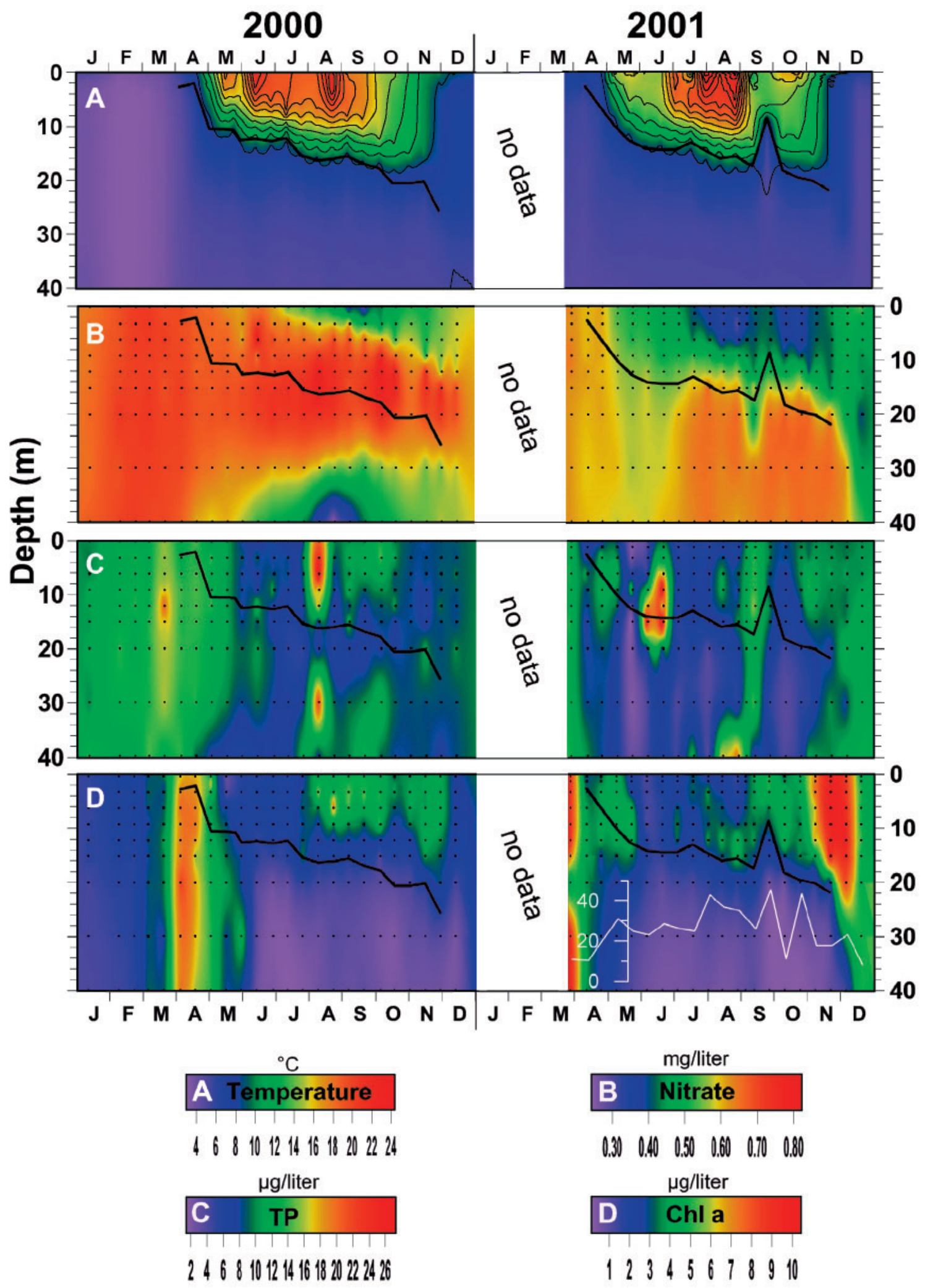

Fig. 5. Seasonal and vertical distributions of (A) temperature $\left({ }^{\circ} \mathrm{C}\right)$ and density contours, (B) nitrate $\left(\mathrm{mg} \mathrm{l} \mathrm{l}^{-1}\right)$, (C) total phosphorus $\left(\mathrm{TP} \mu \mathrm{g} \mathrm{l}^{-1}\right.$ ) and (D) chl a $\left(\mu \mathrm{g} \mathrm{l^{-1 }}\right.$ ) for Years 2000 and 2001. Depth $(\mathrm{m})$ of the upper hypolimnetic boundary is shown by the black curve. Insert: \% biomass contribution of solitary picoplankton for top $12 \mathrm{~m}$ water column (white curve). Discrete samples (Panels B to D) were taken at the dates and depths indicated by grid points 


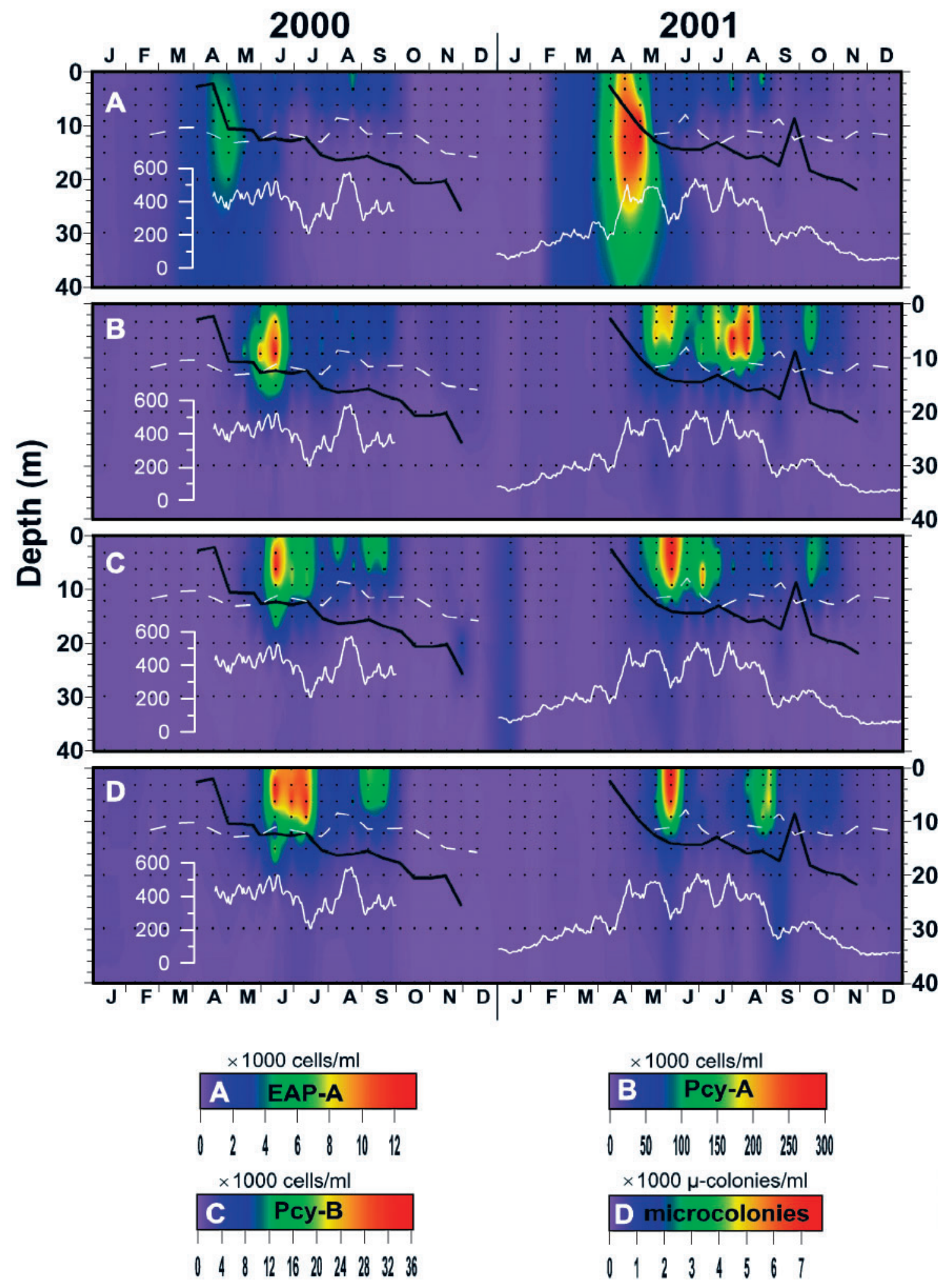

Fig. 6. Seasonal and vertical distributions of (A) EAP-A, (B) Pcy-A, (C) Pcy-B and (D) microcolony populations. EAP-A = eukaryotic picoplankton; Pcy-A and -B = picocyanobacteria populations. Depth (m) of the upper hypolimnetic boundary and $1 \%$ surface light level are shown by the solid black and dashed white curves, respectively. Inserts: left axis and solid white curve: daily mean instantaneous surface PAR (SPAR Inst.-meani $\mu$ mol quanta $\mathrm{m}^{-2} \mathrm{~s}^{-1}$ ). Discrete samples were taken at the dates and depths indicated by grid points 


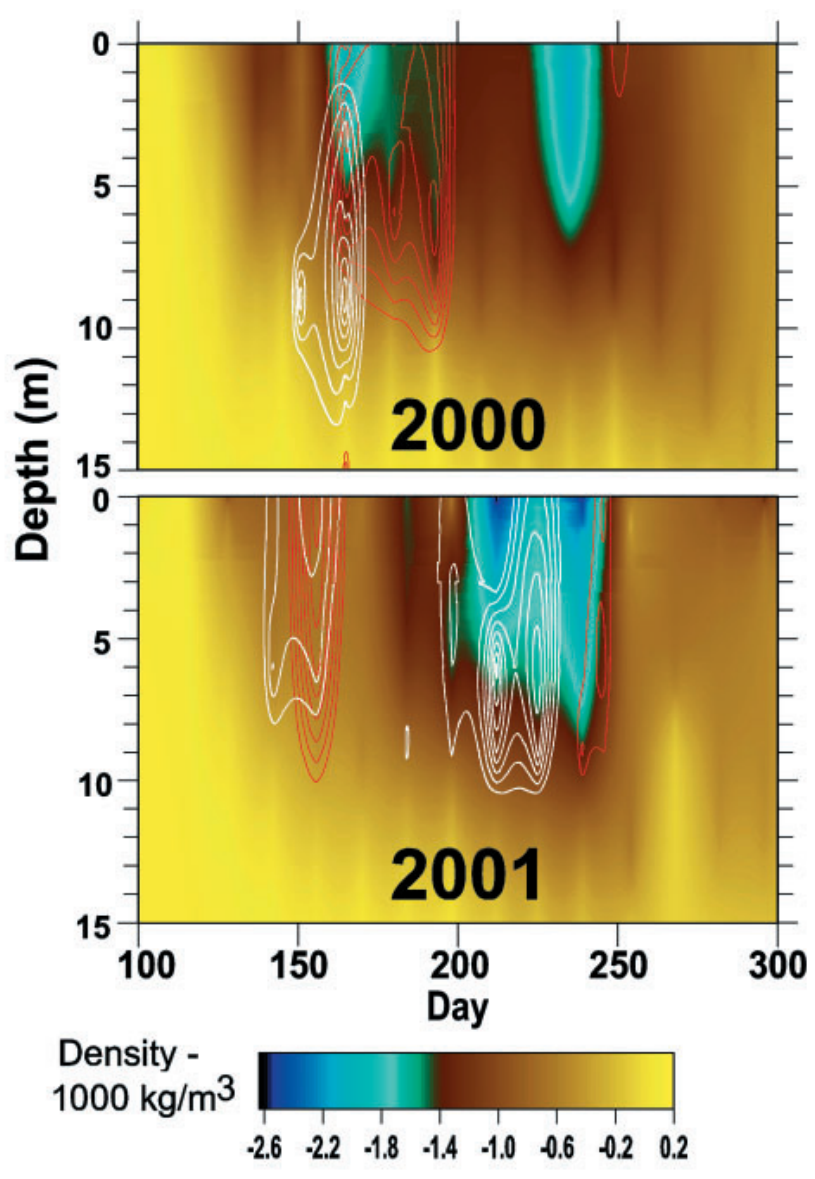

Fig. 7. Density in surface waters, for Years 2000 and 2001, between Days 100 and 300. Red contours show microcolony abundances $>4 \times 10^{3}$ cells $\mathrm{ml}^{-1}$. White contours show picocyanobacteria-A (Pcy-A) abundances $>160 \times 10^{3}$ cells ml $^{-1}$ ability was reduced, at which time short-lived 'blooms' of Pcy-B cells were observed (Fig. 6B-D). Finally, a weak positive correlation between microcolony abundance and $\mathrm{pH}$ was also observed during the stratified period (Fig. 8).

\section{DISCUSSION}

This is the first study to use flow cytometry to characterize the population dynamics of freshwater autotrophic picoplankton (APP) over a full seasonal cycle. Using flow cytometry, we could efficiently and precisely enumerate 4 subpopulations among the APP, several of which had been lumped together in previous studies where epifluorescence microscopy was used to count APP (e.g. Søndergaard 1991, Weisse \& Kenter 1991, Callieri \& Piscia 2002). The refined analysis allows us to draw safer conclusions as to the potential causes for the observed seasonal variation among freshwater APP populations.

\section{Population dynamics of single-celled picocyanobacteria}

The seasonal and vertical distribution of APP populations in Lake Mondsee followed a pattern which was, in general, similar to that described for comparable lakes (Weisse 1993, Stockner et al. 2000). Phycocyaninrich cells were rare, as is typical of prealpine lakes of oligotrophic or oligomesotrophic status, where the light regime likely favours phycoerythrin-rich cells

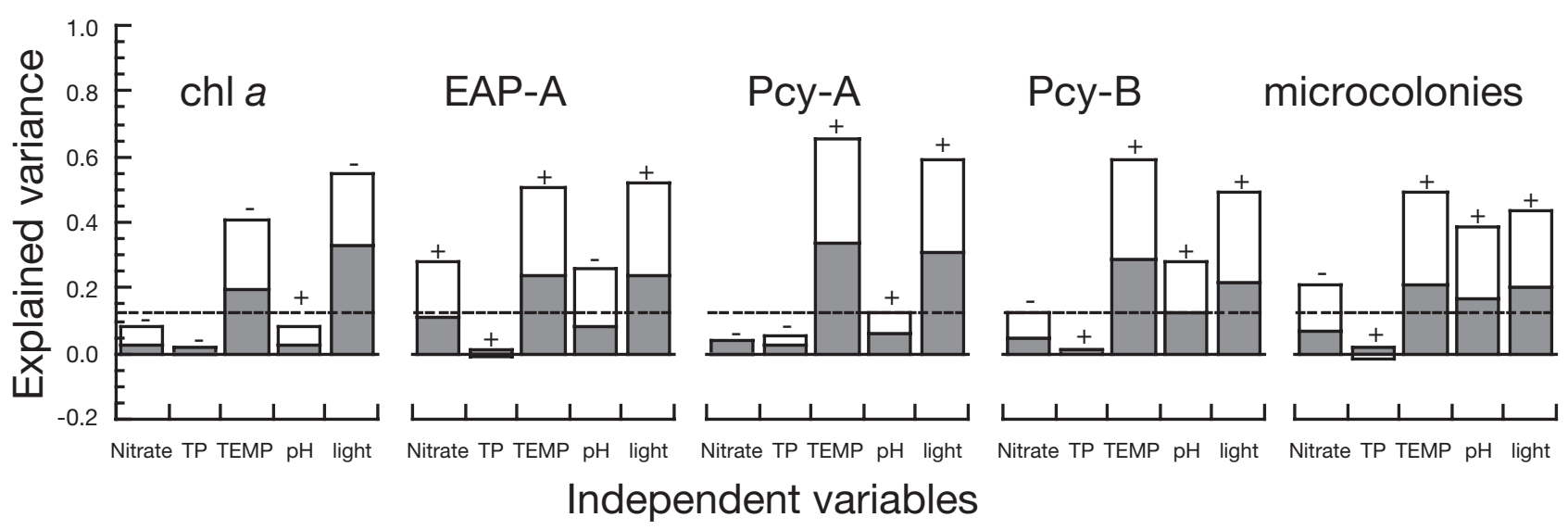

Fig. 8. Proportions of explained variance for depth-weighted average values measured for water columns of $12 \mathrm{~m}$ depth (results of hierarchical partitioning analysis): independent (dark) and joint (clear) components for 4 independent variables related to seasonal depth-weighted average chl a concentrations and autotrophic picoplankton (APP) population abundances. The sum of the independent and joint components from hierarchical partitioning equals the univariate $\mathrm{r}^{2}$ for each variable. The horizontal dashed line indicates a significant correlation $(\mathrm{p}<0.05$, for 24 fortnightly sampling dates during the stratified periods of Years 2000 and 2001). For each independent variable, the type of slope (positive or negative) in standard multiple linear regression analysis is indicated by the symbols ' + ' and ' - '. Values for APP population abundances were $\log _{10}$-transformed prior to hierarchical partitioning and standard multiple linear regression analyses. TEMP $=$ temperature $\left({ }^{\circ} \mathrm{C}\right) ; \mathrm{TP}=$ total phosphorus 
(Vörös et al. 1998), particularly deeper in the water column (i.e. near or below the $1 \%$ surface light depth: Gervais et al. 1997, this study). Unlike prealpine Lake Constance (Weisse 1988, Weisse \& Kenter 1991, Gaedke \& Weisse 1998) and Lake Maggiore (Passoni et al. 1997), however, there was no evidence for a spring peak in solitary picocyanobacteria.

In Lake Constance, the pronounced spring peak regularly observed in the late 1980s and early 1990s was less pronounced in the mid and late 1990s at reduced phosphorus levels (Gaedke \& Weisse 1998). These authors also pointed to the significance of physical factors for the development of a pronounced APP spring maximum; a strong spring peak of picocyanobacteria was only observed in years with an early onset of stratification and a resulting reduced vertical mixing intensity. Weak stratification in March/April and relatively deep vertical mixing (Fig. 5A) may thus explain why we did not observe a spring maximum of picocyanobacteria in Lake Mondsee.

Grazing is largely responsible for the early summer decline in the abundance of solitary picocyanobacteria in Lake Constance (Weisse 1988). Since we observed, however, that declines in the depth-weighted average abundance of solitary picocyanobacteria were associated with extended periods of reduced light availability, low relative growth rates may also be an important factor.

\section{Population dynamics of colonial picocyanobacteria}

Little is known about the formation of picocyanobacterial microcolonies (Weisse 1993, Stockner et al. 2000); these are often not counted or distinguished unequivocally from single-cell forms in published studies. Although the in situ formation of clusters of phytoplankton cells can result from both active and passive factors, several of which are likely to operate in combination (Kiørboe \& Hansen 1993, Young et al. 2001), the mucilage production when cell numbers increase greatly facilitates clump formation (Kiørboe \& Hansen 1993). Mucilage production is likely to have been an important factor in the development of the microcolonies observed in this study, since most microcolonies were found to be embedded in a mucilage which could be weakly stained by DAPI (Crosbie et al. unpubl. data).

Phytoplankton inhabiting oligo-mesotrophic prealpine lakes experience severe phosphorus limitation during summer and autumn (e.g. Hochstädter 2000). The high abundance of microcolonies during such periods of severe nutrient limitation (Pedrós-Alió \& Brock 1983, Klut \& Stockner 1991, the present study) has prompted several authors (Pedrós-Alió \& Brock
1983, Klut \& Stockner 1991) to suggest that colony formation is a strategy for more efficient nutrient recycling. Excretion of mucilage, however, strongly limits diffusive uptake (Ploug et al. 1999), particularly for cells located towards the centre of colonies which would become diffusion limited and deprived of nutrients scavenged by adsorption in the mucus and nutrient uptake by peripheral cells. Consequently, colony cells would grow more slowly than free-living cells; colony formation as a strategy for more efficient nutrient recycling appears, therefore, to be unlikely (Ploug et al. 1999). Whilst these arguments are derived from studies of the colony-forming marine alga Phaeocystis, they remain qualitatively applicable to picocyanobacterial microcolonies. Indeed, the results of field and laboratory studies suggest that cyanobacteria produce a photosynthate-rich mucilage when cells experience severe nutrient deficits whilst being photosynthetically active (Lange 1976, Lehmann \& Wöber 1976, De Philippis et al. 1996, Dubinsky \& BermanFrank 2001). Under such conditions, cyanobacteria and other phytoplankton accumulate large amounts of photosynthate. The capacity of the cell to store photosynthate is limited and any additional photosynthate is excreted; additionally, leakage or excretion of photosynthate may protect phytoplankton from photochemical damage by accommodating the rapidly produced biochemical reductants that are supplied by the light reactions of photosynthesis (Wood \& Van Valen 1990). Small cells in particular have an increased potential for cell-volume-specific leakage of accumulated resources (Raven 1986, Malinsky-Rushansky \& Legrand 1996).

If microcolony mucilage production results from a kind of overflow and/or photoprotective metabolism caused by a combination of severe nutrient deficiency and active photosynthesis, then the formation and persistence of microcolonies should occur most frequently at near-surface depths during periods of calm and sunny weather, particularly in sheltered lakes where populations may be held near to the surface for long periods. In support of this hypothesis, we observed a positive correlation between microcolony standing stocks and $\mathrm{pH}$, which was likely a consequence of the association of microcolonies with periods of calm, sunny weather, i.e. high sunshine hours and low wind speed. At such times, photosynthetic activity by APP and other phytoplankton elevates near-surface $\mathrm{pH}$ in hard water lakes (BermanFrank \& Zohary 1994, Maberly 1996, Stiller \& Nissenbaum 1999).

Grazing may be another factor impacting upon the formation of picocyanobacterial microcolonies (Stockner 1991), although a mechanism for microcolony induction by grazers has not been elucidated. In the well-studied colony-forming alga Scenedesmus, 
colony formation is thought to be linked to specific chemicals associated with producer-grazer interactions, and to general excretory products such as urea (Wiltshire \& Lampert 1999) or other nutrients (Kaler et al. 2000). The alga's light and nutrient history, however, is known to be vital to colony induction (Siver \& Trainor 1981, Wiltshire \& Lampert 1999).

It has recently been stated by Stockner et al. (2000) that the abundance of microcolonies in many lakes is higher at the base of the euphotic zone than in surface waters (Stockner \& Shortreed 1991, SimeNgando 1995). Schallenberg \& Burns (2001), who reported highly significant positive correlations between the abundance of aggregated picocyanobacteria in Lake Wakatipu and concentrations of total phosphorus and total nitrogen, suggested that colonial picocyanobacteria respond positively to small increases in total nutrient concentrations and that colonial picocyanobacteria may contribute significantly to nitrogen fixation within the pelagial. Both Stockner et al. (2000) and Schallenberg \& Burns (2001), however, draw these conclusions based upon relatively limited sampling resolution (a single sampling depth, $10 \mathrm{~m}$, in the case of Schallenberg \& Burns 2001), whereas our analyses, based upon far more extensive sampling in both time and space, suggest that the majority of microcolonies are produced in nutrient-poor surface waters and that their accumulation towards the base of the epilimnion results from physical rather than biological processes.

Whatever the factors leading to the production of microcolonies, the close correlation between solitary picocyanobacteria and microcolonies suggests that microcolonies are derived from solitary cells (e.g. Passoni \& Callieri 2000), at least during summer months. Conversely, fragmentation of microcolonies was likely the cause of increases in Pcy-B abundance during a period of stormy weather. Sonication of sorted microcolonies (results herein) suggest that Pcy-A cells would also be liberated during in situ colony fragmentation, indeed in much greater numbers than Pcy-B cells. The liberation of colony-derived Pcy-A and -B cells, however, would be very difficult to separate from increases in free-living picocyanobacteria due to increased growth of and/or reduced grazing upon the latter cell type. Yet we observed (epifluorescence microscopy count) that microcolonies can reach abundances exceeding 18000 colonies $\mathrm{ml}^{-1}$, constituting what appears to be a significant proportion of the total autotrophic biomass (we did not attempt quantification of actual colony cell numbers since this is currently subject to considerable error; Stockner et al. 2000). Should this be verified, future ecological studies involving freshwater picocyanobacteria will need to take account of processes causing colony formation and fragmentation. Otherwise both growth and mortality estimates of freshwater picocyanobacteria may be subject to considerable error. This would be particularly true in instances where dislodged picocyanobacteria exhibit a metabolic activity which is significantly different to that of their free-living counterparts.

\section{Population dynamics of eukaryotic picoplankton and significance of APP relative to larger phytoplankton}

In contrast to picocyanobacteria, we found clear evidence for a spring peak in EAP during both years of the study. A spring peak in EAP cells has also been observed in the Great Laurentian lakes and in Lake Stechlin (Fahnenstiel et al. 1991, Padisak et al. 1997), at which time EAP populations are known to exhibit high growth rates (Fahnenstiel et al. 1991, Crosbie et al. unpubl. data).

Compared with APP, 'large' phytoplankton (e.g. nanoplanktonic diatoms) cannot as effectively harvest light in stratified water columns, nor can they as effectively utilize the very low concentrations of nutrients that characterize these (typically) highly oligotrophic systems (Raven 1998, Furnas \& Crosbie 1999, Crosbie \& Furnas 2001b). Conversely, greater storage capacity and 'rotational benefits' (to light harvesting: Raven 1996, Raven \& Kübler 2002 and reference cited therein; and nutrient uptake: Raven 1986, 1998, Karp-Boss et al. 1996) must provide diatoms and other large phytoplankton with a significant competitive advantage during periods of deep mixing. Eukaryotic autotrophic picoplankton, having cellular volumes that are several times that of picocyanobacteria, likely fall between picocyanobacteria and nanoplanktonic phytoplankton with respect to their capacity to take up and store nutrients and to harvest light under turbulent conditions. Together with the higher metabolic requirements of EAP cells relative to picocyanobacteria (Weisse 1993), such factors would contribute to an 'intermediate' seasonal peak of EAP cells; i.e. the commencement of stratification, a period when water temperatures are rising and nutrients and mixing are reduced, but not to levels experienced by phytoplankton during summer and autumn.

Acknowledgements. We thank 2 anonymous reviewers for helping to improve an earlier version of the manuscript. Funding and material support was provided by the Austrian Research Fund (grant no. P 14238). We are grateful to the Institute for Fisheries Biology (Scharfling, Upper Austria) and M. Dokulil for providing unpublished environmental/ ecological data, and to P. Stadler, H. Gollmann, L. Eisl and M. Schauer for assistance in the lab and field. 


\section{LITERATURE CITED}

APHA (1992) Standard methods. For examination of water and wastewater. 18th edn. American Public Health Association, Washington, DC

Bäuerle E, Ollinger D, Ilmberger J (1998) Some meteorological, hydrological, and hydrodynamical aspects of Upper Lake Constance. Arch Hydrobiol Spec Issues Adv Limnol 53:143-158

Bell T, Kalff J (2001) The contribution of picophytoplankton in marine and freshwater systems of different trophic status and depth. Limnol Oceanogr 46:1243-1248

Berman-Frank I, Zohary T (1994) $\mathrm{CO}_{2}$ availability, carbonic anhydrase, and the annual dinoflagellate bloom in Lake Kinneret. Limnol Oceanogr 39:1822-1834

Callieri C, Piscia R (2002) Photosynthetic efficiency and seasonality of autotrophic picoplankton in Lago Maggiore after its recovery. Freshw Biol 47:941-956

Callieri C, Stockner J (2000) Picocyanobacteria success in oligotrophic lakes: fact or fiction? J Limnol 59:72-76

Callieri C, Stockner J (2002) Freshwater autotrophic picoplankton: a review. J Limnol 61:1-14

Chevan A (1991) Hierarchical partitioning, v. 1.0. University of Massachusetts, Amherst

Chevan A, Sutherland M (1991) Hierarchical partitioning. Am Stat 45:90-96

Cole GA (1994) Textbook of limnology, 4th edn. Waveland Press, Prospect Heights, IL

Crosbie ND, Furnas MJ (2001a) Abundance, distribution and flow-cytometric characterization of picophytoprokaryote populations in central $\left(17^{\circ} \mathrm{S}\right)$ and southern $\left(20^{\circ} \mathrm{S}\right)$ shelf waters of the Great Barrier Reef. J Plankton Res 23:809-828

Crosbie ND, Furnas MJ (2001b) Net growth rates of picocyanobacteria and nano-/microphytoplankton inhabiting shelf waters of the central $\left(17^{\circ} \mathrm{S}\right)$ and southern $\left(20^{\circ} \mathrm{S}\right)$ Great Barrier Reef. Aquat Microb Ecol 24:209-224

De Philippis R, Sili C, Vincenzini M (1996) Response of an exopolysaccharide-producing heterocystous cyanobacterium to changes in metabolic carbon flux. J Appl Phycol 8:275-281

Dokulil M, Jäger P (1985) General limnological characterization of the Trumer Lakes, Mondsee, Attersee and Traunsee. In: Danielopol D, Schmidt R, Schultze E (eds) Contributions to the paleolimnology of the Trumer Lakes (Salzburg) and the lakes Mondsee, Attersee and Traunsee. Limnology Institute, Austrian Academy of Sciences, Mondsee, p 16-24

Dokulil M, Skolaut C (1986) Succession of phytoplankton in a deep stratifying lake: Mondsee, Austria. Hydrobiologia 138:9-24

Dubinsky Z, Berman-Frank I (2001) Uncoupling primary production from population growth in photosynthesizing organisms in aquatic ecosystems. Aquat Sci 63:4-17

Fahnenstiel GL, Carrick HJ (1992) Phototrophic picoplankton in lakes Huron and Michigan: abundance, distribution, composition and contribution to biomass and production. Can J Fish Aquat Sci 49:379-388

Fahnenstiel GL, Sicko-Goad L, Scavia D, Stoermer EF (1986) Importance of picoplankton in Lake Superior. Can J Fish Aquat Sci 43:235-340

Fahnenstiel GL, Carrick HJ, Rogers CE, Sicko-Goad L (1991) Red fluorescing phototrophic picoplankton in the Laurentian Great Lakes: what are they and what are they doing? Int Rev Ges Hydrobiol 76:603-616

Fogg GE (1995) Some comments on picoplankton and its importance in the pelagic ecosystem. Aquat Microb Ecol 9:33-39
Furnas MJ, Crosbie ND (1999) In situ growth dynamics of photosynthetic prokaryotic picoplankton. In: Charpy L, Larkum AWD (eds) Marine cyanobacteria. Bulletin de l'Institut Océanographique, Monaco, Spec Issue, p 387-417

Gaedke U, Weisse T (1998) Seasonal and interannual variability of picocyanobacteria in Lake Constance. Arch Hydrobiol Spec Issue Adv Limnol 53:143-158

Gervais F, Padisak J, Koschel R (1997) Do light quality and low nutrient concentration favor picocyanobacteria below the thermocline of the oligotrophic lake Stechlin? J Plankton Res 19:771-781

Golden Software (1999) Surfer ${ }^{\circledR}$ (v. 7). Golden, CO

Hepperle D, Krienitz L (2001) Systematics and ecology of chlorophyte picoplankton in German inland waters along a nutrient gradient. Int Rev Ges Hydrobiol 86(3):269-284

Hochstädter S (2000) Seasonal changes in C:P ratios in seston, bacteria, phytoplankton and zooplankton in a deep, mesotrophic lake. Freshw Biol 44:453-463

Jagsch A (1982) Mondsee. In: Sampl H, Gusinde RE, Tomek $\mathrm{H}$ (eds) Seenreinhaltung in Österreich. LimnologieHygiene-Maßnahmen-Erfolge. BM Land- und Forstwirtschaft, Wien, p 155-163

Kaler VL, Bulko OP, Reshnetnikov VN, Galkovskaya GA (2000) Changes in the morphostructure of Scenedesmus acutus and culture growth rate induced by the exudate of primary consumer Daphnia magna. Russ J Plant Physiol 47:698-705

Karp-Boss L, Boss E, Jumars PA (1996) Nutrient fluxes to planktonic osmotrophs in the presence of fluid motion. Oceanogr Mar Biol Annu Rev 34:71-107

Kiørboe T, Hansen JLS (1993) Phytoplankton aggregate formation-observations of patterns and mechanisms of cell sticking and the significance of exopolymeric material. J Plankton Res 15:993-1018

Kirk JTO (1994) Light and photosynthesis in aquatic ecosystems, 2nd edn. Cambridge University Press, Cambridge

Klee R, Schmidt R (1987) Eutrophication of Mondsee (Upper Austria) as indicated by diatom stratigraphy of a sediment core. Diatom Res 2:55-76

Klut EM, Stockner JG (1991) Picoplankton associations in an ultra-oligotrophic lake on Vancouver Island, British Columbia. Can J Fish Aquat Sci 48:1092-1099

Krienitz L, Takeda H, Hepperle D (1999) Ultrastructure, cell wall composition, and phylogenetic position of Pseudodictyosphaerium jurisii (Chlorococcales, Chlorophyta) including a comparison with other picoplanktonic green algae. Phycologia 38:100-107

Lange W (1976) Speculations on a possible essential function of the gelatinous sheath of blue-green algae. Can J Microbiol 22:1181-1185

Lehmann M, Wöber G (1976) Accumulation, mobilization and turnover of glycogen in the blue-green bacterium Anacystis nidulans. Arch Microbiol 111:93-97

Li WKW, Wood AM (1988) Vertical distribution of North Atlantic ultraphytoplankton: analysis by flow cytometry and epifluorescence microscopy. Deep-Sea Res 35:1615-1638

Maberly SC (1996) Diel, episodic and seasonal changes in pH and concentrations of inorganic carbon in a productive lake. Freshw Biol 35:579-598

MacIsaac EA, Stockner JG (1993) Enumeration of phototrophic picoplankton by autofluorescence microscopy. In: Kemp PF, Sherr BF, Sherr EB, Cole JJ (eds) Handbook of methods in aquatic microbial ecology. Lewis Publishers, Boca Raton, FL, p 187-197

MacNally R (2000) Regression and model-building in conservation biology, biogeography and ecology: the distinction between - and reconciliation of - 'predictive' and 'explana- 
tory' models. Biodiversity Conserv 9:655-671

Malinsky-Rushansky NZ, Legrand C (1996) Excretion of dissolved organic carbon by phytoplankton of different sizes and subsequent bacterial uptake. Mar Ecol Prog Ser 132: 249-255

Olson RJ, Zettler ER, DuRand MD (1993) Phytoplankton analysis using flow cytometry. In: Kemp PF, Sherr BF, Sherr EB, Cole JJ (eds) Handbook of methods in aquatic microbial ecology. Lewis Publishers, Boca Raton, FL, p 175-186

Padisak J, Krienitz L, Koschel R, Nedoma J (1997) Deep-layer autotrophic picoplankton maximum in the oligotrophic lake Stechlin, Germany-origin, activity, development and erosion. Eur J Phycol 32:403-416

Passoni S, Callieri C (2000) Picocyanobacteria single forms, aggregates and microcolonies: survival strategy or species succession? Verh Int Ver Limnol 27:1879-1883

Passoni S, Callieri C, Heinimaa S (1997) Dinamiche di distribuzione del picoplancton autotrofo nel Lago Maggiore. Piccazzo, M. Proc. 12th AIOL Congress (Italian Association for Oceanography and Limnology), 1:109-118

Pedrós-Alió C, Brock TD (1983) The importance of attachment to particles for planktonic bacteria. Arch Hydrobiol 98:354-379

Pick FR, Agbeti M (1991) The seasonal dynamics and composition of photosynthetic picoplankton communities in temperate lakes in Ontario, Canada. Int Rev Ges Hydrobiol 76:565-580

Ploug H, Stolte W, Jørgensen BB (1999) Diffusive boundary layers of the colony-forming plankton alga Phaeocystis sp.-_implications for nutrient uptake and cellular growth. Limnol Oceanogr 44:1959-1967

Raven JA (1986) Physiological consequences of extremely small size for autotrophic organisms in the sea. In: Platt $T$, Li WKW (eds) Photosynthetic picoplankton. Can Bull Fish Aquat Sci 214:1-70

Raven JA (1996) The bigger the fewer: size, taxonomic diversity and the range of chlorophyll(lide) pigments in oxygen-evolving marine photolithotrophs. J Mar Biol Assoc UK 76:211-217

Raven JA (1998) The twelfth Tansley lecture-small is beautiful-the picophytoplankton. Funct Ecol 12:503-513

Raven JA, Kübler JE (2002) New light on the scaling of metabolic rate with the size of algae. J Phycol 38:11-16

Schallenberg M, Burns CW (2001) Tests of autotrophic picoplankton as early indicators of nutrient enrichment in an ultra-oligotrophic lake. Freshw Biol 46(1):27-37

Sime-Ngando T (1995) Population dynamics of autotrophic picoplankton in relation to environmental factors in a productive lake. Aquat Sci 57:91-105

Editorial responsibility: William Li, Dartmouth, Nova Scotia, Canada
Siver PA, Trainor FR (1981) Morphological control and physiology of Scenedesmus strain 170. Phycologia 20:1-11

Søndergaard M (1991) Phototrophic picoplankton in temperate lakes: seasonal abundance and importance along a trophic gradient. Int Rev Ges Hydrobiol 76:505-522

SPSS (1997) SigmaStat ${ }^{\circledR} 2.0$ for Windows ${ }^{\circledR}$. SPSS, Chicago

Stiller M, Nissenbaum A (1999) A stable isotope study of dissolved inorganic carbon in hardwater Lake Kinneret (Sea of Galilee). S Afr J Sci 95:166-170

Stockner JG (1991) Autotrophic picoplankton in freshwater ecosystems: the view from the summit. Int Rev Ges Hydrobiol 76:483-492

Stockner JG, Antia NJ (1986) Algal picoplankton from marine and freshwater ecosystems: a multidisciplinary perspective. Can J Fish Aquat Sci 43:2472-2503

Stockner JG, Shortreed KS (1991) Autotrophic picoplankton: community composition, abundance and distribution across a gradient of oligotrophic British Columbia and Yukon Territory lakes. Int Rev Ges Hydrobiol 76:581-601

Stockner J, Callieri C, Cronberg G (2000) Picoplankton and other non-bloom forming cyanobacteria in lakes. In: Whitton B, Potts M (eds) Kluwer Academic, Dordrecht, p 195-231

Thompson JB, Schultze-Lam S, Beveridge J, Des Marais DJ (1997) Whiting events: biogenic origin due to the photosynthetic activity of cyanobacterial picoplankton. Limnol Oceanogr 42:133-141

Vörös L, Callieri C, Balogh KV, Bertoni R (1998) Freshwater picocyanobacteria along trophic gradient and light quality range. Hydrobiologia 369/370:117-125

Wehr JD (1991) Experimental tests of nutrient limitation in freshwater picoplankton. Appl Env Microbiol 55:1605-1611

Weisse $\mathrm{T}$ (1988) Dynamics of autotrophic picoplankton in Lake Constance. J Plankton Res 10:1179-1188

Weisse T (1993) Dynamics of autotrophic picoplankton in marine and freshwater ecosystems. In: Jones JG (ed) Advances in microbial ecology, 13. Plenum Press, New York, p 327-370

Weisse T, Kenter U (1991) Ecological characteristics of autotrophic picoplankton in a prealpine lake. Int Rev Ges Hydrobiol 76:493-504

Wiltshire KH, Lampert W (1999) Urea excretion by Daphnia: a colony-inducing factor in Scenedesmus? Limnol Oceanogr 44:1894-1903

Wood AM, Van Valen LM (1990) Paradox lost? On the release of energy-rich compounds by phytoplankton. Mar Microb Food Webs 4:103-116

Young WR, Roberts AJ, Stuhne G (2001) Reproductive pair correlations and the clustering of organisms. Nature 412: 328-331

Submitted: November 20, 2002; Accepted: March 31, 2003 Proofs received from author(s): July 10, 2003 